\title{
Ingestion of the unicellular cyanobacterium Synechococcus by the mixotrophic red tide ciliate Mesodinium rubrum
}

\author{
Yeong Du Yoo ${ }^{1}$, Kyeong Ah Seong ${ }^{2}$, Geumog Myung ${ }^{1}$, Hyung Seop Kim ${ }^{1}$, Hae Jin Jeong ${ }^{3}$, \\ Brian Palenik ${ }^{4}$ and Wonho Yih ${ }^{1, *}$
}

${ }^{1}$ Department of Marine Biotechnology, College of Ocean Science and Technology, Kunsan National University, Kunsan 54150, Korea

${ }^{2}$ Converging Research Division, National Marine Biodiversity Institute of Korea, Chungnam 33662, Korea

${ }^{3}$ School of Earth and Environmental Sciences, College of Natural Sciences, Seoul National University, Seoul 08826, Korea

${ }^{4}$ Marine Biology Research Division, Scripps Institution of Oceanography, University of California at San Diego, La Jolla, CA 92093-0202, USA

We explored phagotrophy of the phototrophic ciliate Mesodinium rubrum on the cyanobacterium Synechococcus. The ingestion and clearance rates of M. rubrum on Synechococcus as a function of prey concentration were measured. In addition, we calculated grazing coefficients by combining the field data on abundance of M. rubrum and co-occurring Synechococcus spp. with laboratory data on ingestion rates. The ingestion rate of M. rubrum on Synechococcus sp. linearly increased with increasing prey concentrations up to approximately $1.9 \times 10^{6}$ cells $\mathrm{mL}^{-1}$, to exhibit sigmoidal saturation at higher concentrations. The maximum ingestion and clearance rates of M. rubrum on Synechococcus were 2.1 cells predator $^{-1} \mathrm{~h}^{-1}$ and $4.2 \mathrm{~nL}$ predator ${ }^{-1} \mathrm{~h}^{-1}$, respectively. The calculated grazing coefficients attributable to $M$. rubrum on cooccurring Synechococcus spp. reached 0.04 day $^{1}$. M. rubrum could thus sometimes be an effective protistan grazer of Synechococcus in marine planktonic food webs. M. rubrum might also be able to form recurrent and massive blooms in diverse marine environments supported by the unique and complex mixotrophic arrays including phagotrphy on hetrotrophic bacteria and Synechococcus as well as digestion, kleptoplastidy and karyoklepty after the ingestion of cryptophyte prey.

Key Words: grazing impact; ingestion; Mesodinium; mixotrophy; Synechococcus

\section{INTRODUCTION}

Mesodinium rubrum Lohmann 1908 is a cosmopolitan species that recurrently forms ciliate red tides in diverse marine environments (Taylor et al. 1971, Lindholm 1985, Crawford 1989, Yih et al. 2013). M. rubrum is able to carry out photosynthesis as well as phagotrophic feeding on prey organisms such as cryptophytes (Yih et al. 2004a,
Johnson and Stoecker 2005, Park et al. 2007, Hansen et al. 2012, 2013) and heterotrophic bacteria (Myung et al. 2006). In turn, M. rubrum is known to be an important prey item for many protistan and metazoan grazers at higher trophic level (Sullivan and Gifford 2004, Yih et al. 2004b, Liu et al. 2005, Park et al. 2006, Reguera et al. 2012,
(9) $\$$ This is an Open Access article distributed under the terms of the Creative Commons Attribution Non-Commercial License (http://creativecommons.org/licenses/by-nc/3.0/) which permits unrestricted non-commercial use, distribution, and reproduction in any medium, provided the original work is properly cited.
Received October 14, 2015, Accepted November 30, 2015

* Corresponding Author

E-mail: ywonho@kunsan.ac.kr

Tel: +82-63-469-4602, Fax: +82-63-469-4990 
Lee et al. 2014). This species usually co-occurs with bacterioplankton (Powell et al. 2005, Jeong et al. 2013) and M. rubrum blooms sometimes succeed those of bacterioplankton (Jeong et al. 2013). Therefore, mixotrophy of M. rubrum is most likely a very important phenomenon for the balanced maintenance of healthy marine environments. To understand the ecology of M. rubrum in marine food web systems, further exploration on the unique aspects of phagotrophy in M. rubrum on several kinds of prey is still desired.

The phototrophic prokaryote Synechococcus is a ubiquitous cyanobacterium in marine ecosystem (Johnson and Sieburth 1979, Waterbury et al. 1979, Marañón et al. 2003, Huang et al. 2012) with its cosmopolitan distribution from tropical to polar waters (Walker and Marchant 1989, Burkill et al. 1993, Landry et al. 1996, Powell et al. 2005). Synechococcus spp. numerically dominate the abundance of phytoplankton in marine environments (Glibert et al. 2004, Murrell and Lores 2004). In addition, Synechococcus sometimes contributes significantly to phytoplankton biomass and primary production in marine ecosystem (Glover et al. 1986, Li 1994, Jeong et al. 2013). It is known to be one of the major contributors to $\mathrm{CO}_{2}$ and nutrient uptake from the ocean waters (Marañón et al. 2003). Therefore, the growth and mortality of Synechococcus are important factors in understanding the cycling of biomaterials in marine microbial food webs.

Several protistan grazers are known to ingest Synechococcus (Christaki et al. 1999, 2002, Jeong et al. 2005, 2010, 2012, Apple et al. 2011, Strom et al. 2012). The marine ciliate $M$. rubrum has been found to co-occur with Synechococcus spp. in the coastal waters (Lignell et al. 2003, Jeong et al. 2013, Liu et al. 2013). Therefore to better understand Mesodinium bacterivory in microbial food webs, we investigated the predator-prey relationships between M. rubrum and Synechococcus.

We explored whether M. rubrum is able to feed on Synechococcus. We also measured the ingestion rates of M. rubrum on Synechococcus as a function of prey concentration. In addition, we estimated grazing coefficients attributable to M. rubrum on co-occurring Synechococcus using our data for ingestion rates obtained from the laboratory experiments and data on the abundance of Mesodinium and Synechococcus in the field. The results of the present study provide a basis for improved estimation and understanding the population dynamics of $M$. rubrum in marine ecosystems.

\section{MATERIALS AND METHODS}

\section{Preparation of experimental organisms}

For isolation and cultivation of Mesodinium rubrum strain MR-MAL01 (Table 1) plankton samples were collected from Gomso Bay, Korea, during May 2001 when the water temperature and salinity were $18.0^{\circ} \mathrm{C}$ and 31.5 , respectively. A culture of M. rubrum was established by serial single-cell isolations (Yih et al. 2004a). The cryptophyte Teleaulax amphioxeia strain CR-MAL01 (Yih et al. 2004a) was offered as prey of M. rubrum. Both M. rubrum and $T$. amphioxeia were maintained at $20^{\circ} \mathrm{C}$ in $\mathrm{f} / 2 \mathrm{me}-$ dium (Guillard and Ryther 1962) without silicate under continuous illumination of $20 \mu \mathrm{mol}$ photons $\mathrm{m}^{-2} \mathrm{~s}^{-1}$ of cool white fluorescent light in the walk-in incubator system of the Marine Biology Research and Education Center, Kunsan National University. The phototrophic prokaryote Synechococcus strain CC9311 (clade I) (Table 1) was also grown at $20^{\circ} \mathrm{C}$ in $\mathrm{f} / 2$ medium (Guillard and Ryther 1962) without silicate under continuous illumination of 20 $\mu \mathrm{mol}$ photons $\mathrm{m}^{-2} \mathrm{~s}^{-1}$. This strain has two phycoerythrin proteins (PE I and PE II) (Ong and Glazer 1991).

The equivalent spherical diameter and cell volume of M. rubrum (Table 1) was measured using an electron particle counter (Coulter Multisizer II; Coulter Corporation, Miami, FL, USA). The carbon contents for M. rubrum was estimated from cell volume according to Menden-Deuer and Lessard (2000). The cell volume and carbon content for Synechococcus sp. was adopted from Apple et al. (2011).

Table 1. Origin, strain name, and mean cell volume of the two experimental organisms

\begin{tabular}{ccccc}
\hline \multicolumn{1}{c}{ Organism } & Cell volume & \multicolumn{1}{c}{ Location } & Prey species & References \\
\hline Synechococcus sp. CC9311 & 0.6 & California current, USA & - & Apple et al. (2011) \\
Mesodinium rubrum MR-MAL01 & 5,996 & Gomso Bay, Korea & Teleaulax amphioxeia & Yih et al. (2004a) \\
\hline
\end{tabular}

Cell volume $\left(\mu \mathrm{m}^{3}\right)$ of Mesodinium rubrum was measured by an electronic particle counter. 


\section{Prey concentrations (PCs) effects on ingestion and clearance rates}

Experiment was designed to measure the ingestion and clearance rates of M. rubrum as a function of the PC when fed on Synechococcus sp.

We prepared dense cultures of $M$. rubrum (12,000 cells $\mathrm{mL}^{-1}$ ) and Synechococcus sp. that were separately grown phototrophically in f/2 medium (Guillard and Ryther 1962) without silicate under continuous illumination of $20 \mu \mathrm{mol}$ photons $\mathrm{m}^{-2} \mathrm{~s}^{-1}$. Three $1 \mathrm{~mL}$ aliquots were subsampled from each $M$. rubrum culture for the cell counting under a light microscope (Olympus BH2; Olympus Co., Tokyo, Japan). For the Synechococcus cell counting, $5 \mathrm{~mL}$ aliquots from each Synechococcus culture were removed and then fixed with formalin (final conc. $=4 \%$ ). The fixed sample was stained using DAPI (final conc. $=1$ $\mu \mathrm{M}$ ) and then filtered onto 25 -mm polycarbonate black membrane filters of $0.2 \mu \mathrm{m}$-pore-size. The Synechococcus cells on the membranes were observed under an epifluorescence microscope (Olympus $\mathrm{BH} 2$; Olympus Co.) with UV light excitation at a magnification of $\times 1,000$.

The initial concentrations of M. rubrum and Synechococcus were established using a pipette to deliver predetermined volumes of known cell concentration to the bottles. Triplicate $80 \mathrm{~mL}$ experimental bottles (containing mixtures of M. rubrum and Synechococcus), triplicate prey control bottles (containing Synechococcus only) and triplicate predator control bottles (containing $M$. rubrum only) were also established. All the bottles were placed on a shelf and incubated at $20^{\circ} \mathrm{C}$ under illumination of $20 \mu \mathrm{mol}$ photons $\mathrm{m}^{-2} \mathrm{~s}^{-1}$ of cool white fluorescent light.

After 1-, 10-, 20-, and 30-min incubation periods, 5 $\mathrm{mL}$ aliquots were removed from each bottle, and then fixed with formalin. The fixed samples were stained using DAPI and then filtered onto $3 \mu \mathrm{m}$-pore-sized polycarbonate white membrane filters. Then, the cells of $M$. rubrum with Synechococcus as well as Synechococcus inside a $M$. rubrum were enumerated under an epifluorescence microscope with UV, blue, and green-light excitation at a magnification of $\times 1,000$ by scanning the $M$. rubrum body at consecutive intervals of 1 to $2 \mu \mathrm{m}$ focal depth along the $\mathrm{z}$-axis. We tried to minimize the concentration of heterotrophic bacteria in the M. rubrum culture. For the experiments we subsampled M. rubrum from the upper thin layer with high density of $M$. rubrum using a siphon, and then diluted to the target concentrations by adding auto- claved seawater to the subsamples. Thus, the initial concentrations of heterotrophic bacteria in the experimental bottles were $<16 \%$ of Synechococcus concentrations.

The ingestion rate (IR; cells predator ${ }^{-1} \mathrm{~h}^{-1}$ ) was calculated by linear regression of the number of Synechococcus per $M$. rubrum cell as a function of incubation time as in Sherr et al. (1987).

The clearance rate (CR; $\mathrm{mL}$ predator $\left.{ }^{-1} \mathrm{~h}^{-1}\right)$ was calculated as:

$$
\mathrm{CR}=\mathrm{IR} / \mathrm{PC}
$$

, where IR (cells predator ${ }^{-1} \mathrm{~h}^{-1}$ ) is the ingestion rate of the M. rubrum predator on the Synechococcus prey and PC (cells $\mathrm{mL}^{-1}$ ) is the prey concentration.

Ingestion and clearance rates were calculated using the equations of Frost (1972) and Heinbokel (1978). Data for IRs (cells predator ${ }^{-1} \mathrm{~h}^{-1}$ ) were fitted to a Michaelis-Menten equation:

$$
\mathrm{IR}=\frac{\mathrm{I}_{\max }(\mathrm{x})}{\mathrm{K}_{\mathrm{IR}}+(\mathrm{x})}
$$

, where $\mathrm{I}_{\max }=$ the maximum ingestion rate (MIR; cells predator $^{-1} \mathrm{~h}^{-1}$ ), $\mathrm{x}=\mathrm{PC}\left(\right.$ cells $\mathrm{mL}^{-1}$ ), and $\mathrm{K}_{\mathrm{IR}}=$ the PC sustaining $1 / 2 \mathrm{I}_{\max }$.

\section{Potential grazing impact}

We estimated the grazing coefficients attributable to Mesodinium rubrum on Synechococcus spp. by combining field data on the abundance of M. rubrum and Synechococcus with the ingestion rates of the M. rubrum on Synechococcus sp. obtained in the present study. Field data on the abundance of M. rubrum and co-occurring Synechococcus used in this estimation were originally obtained using the water samples from Masan Bay (20042005), Korea (Jeong et al. 2013).

The grazing coefficient $\left(\mathrm{g} \mathrm{day}^{-1}\right)$ was calculated as:

$$
\mathrm{g}=\mathrm{CR} \times \mathrm{GC} \times 24
$$

, where CR (mL predator-1 $\left.\mathrm{h}^{-1}\right)$ is the clearance rate of a M. rubrum predator on Synechococcus prey at a given PC and GC is a predator concentration (cells $\mathrm{mL}^{-1}$ ). CR values were corrected using $\mathrm{Q}_{10}=2.8$ (Hansen et al. 1997) because in situ water temperatures and the temperature used in the laboratory for this experiment $\left(20^{\circ} \mathrm{C}\right)$ were sometimes different. 

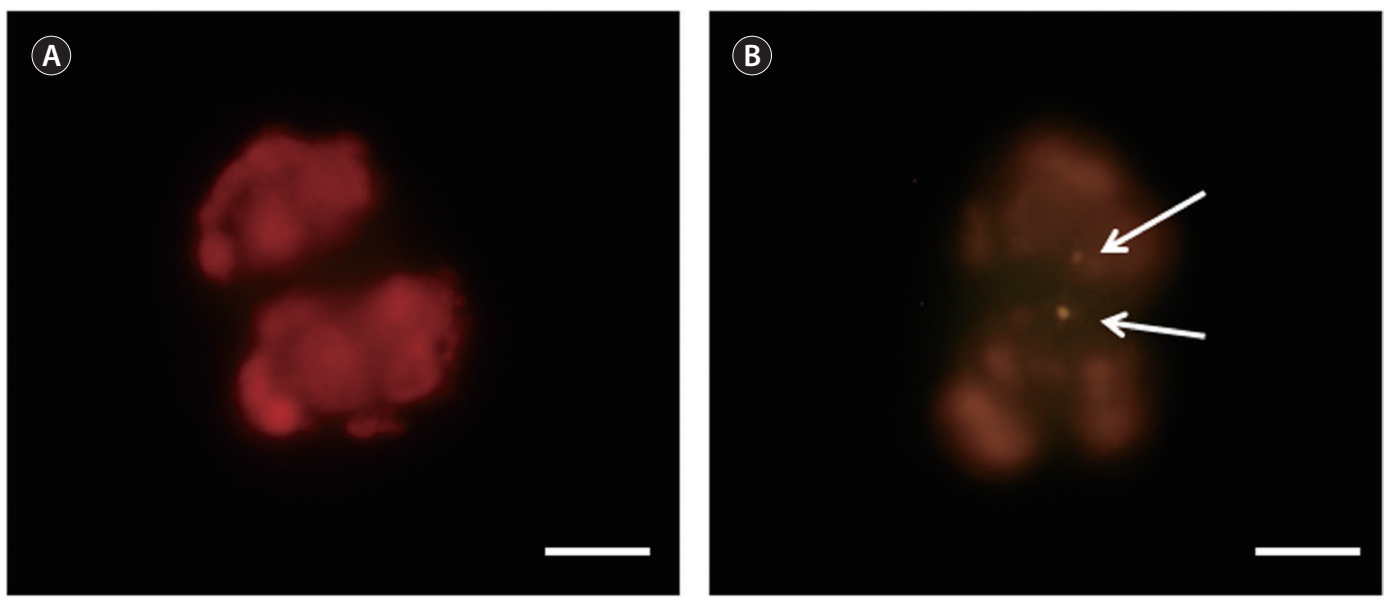

Fig. 1. Epifluorescence images of Mesodinium rubrum with ingested prey Synechococcus sp. (A) An unfed M. rubrum cell under an epifluorescence microscope with green light excitation. (B) M. rubrum with two ingested Synechococcus cells under an epifluorescence microscope with blue light excitation. Arrows indicate ingested prey cells. Scale bars represents: A \& B, $10 \mu \mathrm{m}$.

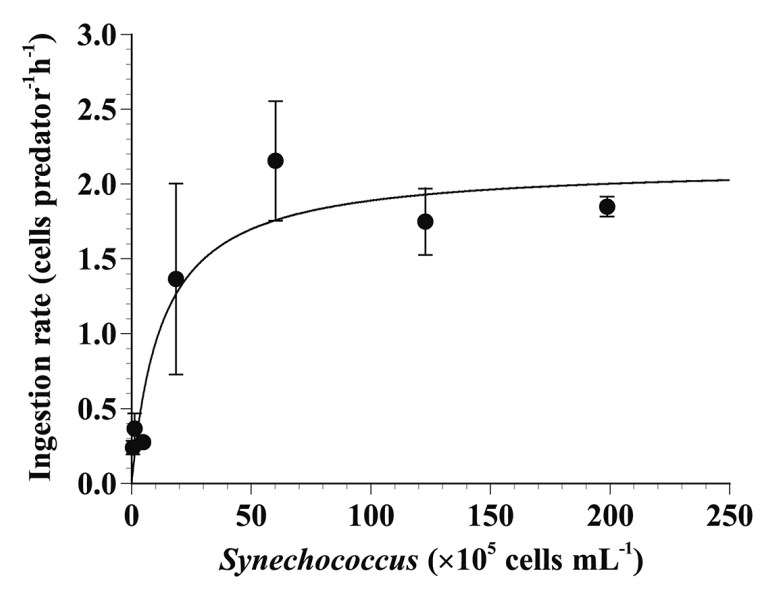

Fig. 2. Specific ingestion rates of the photosynthetic ciliate Mesodinium rubrum on Synechococcus sp. as a function of mean prey concentration $(\mathrm{x})$. Symbols represent treatment means \pm 1 standard error. The curves are fitted by a Michaelis-Menten equation [Eq. (2)] using all treatments in the experiment. Ingestion rate (cells predator ${ }^{-1}$ $\left.h^{-1}\right)=2.1\left[x /\left(1.2 \times 10^{6}+x\right)\right], r^{2}=0.697$.

\section{RESULTS AND DISCUSSION}

\section{PCs effects on ingestion and clearance rates}

We found that M. rubrum ingested Synechococcus cells (Fig. 1). This should be the first report of grazing by red tide ciliate M. rubrum on Synechococcus. M. rubrum commonly co-occurred with Synechococcus in many marine ecosystems (Lignell et al. 2003, Jeong et al. 2013, Liu et al. 2013). Thus, M. rubrum should be considered to be a potentially grazer on Synechococcus in marine planktonic food webs.

The specific ingestion rates (SIRs) of M. rubrum on Synechococcus linearly increased with increasing PCs up to $1.9 \times 10^{6}$ cells $\mathrm{mL}^{-1}$, but exhibit sigmoidal saturation at higher concentrations (Fig. 2). When the data were fitted to Eq. (2), the MIR of M. rubrum was 2.1 cells predator ${ }^{-1} \mathrm{~h}^{-1}$ (0.5 pg C predator ${ }^{-1} \mathrm{~h}^{-1}$ ). In addition, M. rubrum was able to acquire up to $12.6 \mathrm{pg} \mathrm{C}$ from Synechococcus daily. The maximum clearance rate of M. rubrum on Synechococcus was $4.2 \mathrm{~nL}$ predator-1 $\mathrm{h}^{-1}$ (Table 2).

In comparison with MIRs of other red tide organisms when fed on Synechococcus, the MIR of M. rubrum on Synechococcus is quite much lower (Table 3). The maximum of volume SIR (VSIR) of M. rubrum was also lower than that of the other predators. M. rubrum is also able to feed on heterotrophic bacteria with higher SIR than that for Synechococcus (Myung et al. 2006). In addition, M. rubrum fed on exclusively cryptophyte prey species when offered a variety of algal prey species (Park et al. 2007, Myung et al. 2013). Thus, such kind of multiple prey species for the phagotrophy of M. rubrum might have evoked a type of partitioned ingestion with differential prey preferences.

The ingestion rates of the red tide organisms on Synechococcus were affected by the PC. The $\mathrm{K}_{\mathrm{IR}}$ (the mean PC sustaining $1 / 2 \mathrm{I}_{\max }$ of MIR) of $1.2 \times 10^{6}$ cells $\mathrm{mL}^{-1}$ for $M$. rubrum feeding on Synechococcus was relatively higher than that for other predators (Table 3). Therefore, the ingestion of M. rubrum on Synechococcus was less sensitive than that of other red tide organisms to the concentration of prey cells under prey-limited conditions. 
The MIRs of heterotrophic nanoflagellates, mixotrophic dinoflagellates, heterotrophic dinoflagellates, and ciliates feeding on Synechococcus sp. are in general positively correlated with the predator's equivalent spherical diameter ( $p<0.01$, ANOVA) (Table 4, Fig. 3). This relationship suggests that the sizes of the protistan grazers may be an important factor affecting their ingestion rates on Synechococcus. However, the MIR of M. rubrum on Synechococcus is relatively quite lower than that of the other protistan grazers with the exceptions in Picophagus flagellates, Bodo saltans, and Gonimonas pacifica. Furthermore, M. rubrum exhibited jumping behavior (Fenchel and Hansen 2006). This jumping behavior of M. rubrum may be partially responsible for the minimal ingestion. The MIR of Ochromonas sp. feeding on Synechococcus was higher than that of the other protistan grazers with the exception Eutinnuis sp. (Table 4). In addition, the SIR of Ochromonas was higher than that of the other protistan grazers. Thus, Synechococcus was the optimal prey for Ochromonas sp. not for M. rubrum among bacteriovorus protistan grazers.

The MIR of M. rubrum on Synechococcus provided in the present study was higher than that of the small heterotrophic nanoflagellate Picophagus flagellates $(0.18 \mathrm{pg}$ $\mathrm{C}$ predator $\left.\mathrm{r}^{-1} \mathrm{~h}^{-1}\right)$, Bodo saltans $\left(0.12 \mathrm{pg} \mathrm{C}\right.$ predator $\left.\mathrm{r}^{-1} \mathrm{~h}^{-1}\right)$ on

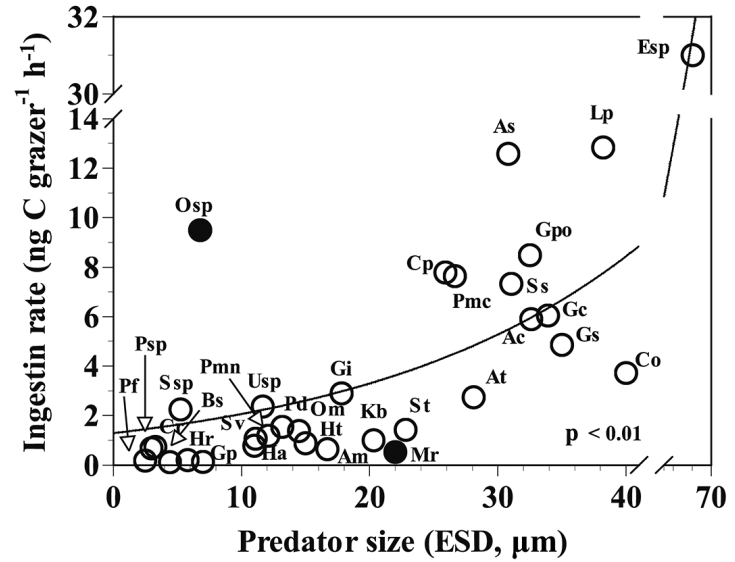

Fig. 3. Ingestion rates of protistan grazers on Synechococcus as a function of predator size (equivalent spherical diameter, ESD, $\mu \mathrm{m}$ ). The equation of the regression was follows: Ingestion rate (ng C predator $\left.^{-1} \mathrm{~h}^{-1}\right)=1.33 \mathrm{e}^{(0.046 \times \mathrm{ESD})}, \mathrm{r}^{2}=0.790$. Ac, Alexandrium catenella; Am, A. minutum; As, Akashiwo sanguinea; At, A. tamarense; Bs, Bodo saltans; $\mathrm{Co}$, Chattonella ovata; $\mathrm{Cp}$, Cochlodinium polykrikoides; $\mathrm{Cr}$, Cafeteria roenbergensis; Esp, Eutintinnus sp.; Gc, Gymnodinium catenatum; Gi, G. impudicum; Gp, Goniomonas pacifica; Gpo, Gonyaulax polygramma; Gs, G. spinifera; Ha, Heterosigma akashiwo; $\mathrm{Hr}$, Heterocapsa rotundata; $\mathrm{Ht}, H$. triquetra; Kb, Karenia brevis; Lp, Lingulodinium polyedrum; Mr, Mesodinium rubrum; Om, Oxyrrhis marina; Osp, Ochromonas sp.; Pd, Prorocentrum donghaiense; Pf, Picophagus flagellates; Pmc, P. micans; Pmn, P. minimum; Psp, Pseudobodo sp.; Ss, Strombidium sulcatum; Ssp, Spumella sp.; St: Scrippsiella trochoidea; Sv, Symbiodinium voratum; Usp, Uronema sp.

Table 2. Comparison of maximum ingestion rates and carbon acquisition in Mesodinium rubrum with three different prey species

\begin{tabular}{lccccccl}
\hline \multicolumn{1}{c}{ Prey species } & PV & MIR & K & MCR & CA & BC & Reference \\
\hline Synechococcus sp. & 0.6 & 0.5 & $1.2 \times 10^{6}$ & 4.2 & 12.6 & 1.2 & This study \\
Heterotropic bacteria & 0.3 & 2.8 & - & 37 & 66.1 & 6.2 & Myung et al. (2006) \\
Teleaulax amphioxeia $^{\text {a }}$ & 76.1 & 1.9 & $2.7 \times 10^{4}$ & - & 44.8 & 5.5 & Yih et al. (2004a) \\
\hline
\end{tabular}

$\mathrm{PV}$, prey volume $\left(\mu \mathrm{m}^{3}\right) ; \mathrm{MIR}$, maximum ingestion rate $\left(\mathrm{pg} \mathrm{C}\right.$ predator $\left.{ }^{-1} \mathrm{~h}^{-1}\right) ; \mathrm{K}_{\mathrm{R}}$, the prey concentration sustaining $1 / 2 \mathrm{MIR}\left(\mathrm{cell} \mathrm{mL}^{-1}\right) ; \mathrm{MCR}, \mathrm{maxi}^{-}$ mum clearance rate $\left(\mathrm{nL}\right.$ predator $\left.{ }^{-1} \mathrm{~h}^{-1}\right) ; \mathrm{CA}$, carbon acquired from prey by predator per day $\left(\mathrm{pg} \mathrm{C}\right.$ predator $\left.\mathrm{d}^{-1}\right) ; \mathrm{BC}$, acquired carbon as percentage of predator's carbon (\%).

The maximum value among the mean ingestion rates measured at given prey concentrations.

Table 3. Comparison of ingestion rates and carbon acquisition of red tide organisms on Synechococcus using prey-inclusion method in the literature

\begin{tabular}{|c|c|c|c|c|c|c|c|}
\hline Red tide organism & Taxon & PD & MIR & $\mathrm{K}_{\mathrm{IR}}$ & MCR & VSIR & Reference \\
\hline Mesodinium rubrum & CIL & 5,996 & 0.5 & 12 & 4.2 & 0.5 & This study \\
\hline Heterosigma akashiwo $^{\mathrm{a}}$ & RAP & 697 & 0.8 & - & 300 & 7.7 & Jeong et al. (2010) \\
\hline Symbiodinium voratum & DIN & 720 & 1.1 & 3.9 & 165.4 & 5.7 & Jeong et al. (2012) \\
\hline Prorocentrum donghaiense & DIN & 1,200 & 1.5 & 1.1 & 2,600 & 5.6 & Jeong et al. (2005) \\
\hline Heterocapsa triquetra & DIN & 1,770 & 0.9 & - & - & 2.4 & Jeong et al. (2005) \\
\hline Alexandrium minutum & DIN & 2,440 & 0.6 & - & - & 1.4 & Jeong et al. (2005) \\
\hline Prorocentrum micans & DIN & 9,900 & 7.6 & 1.5 & 4,300 & 5.9 & Jeong et al. (2005) \\
\hline Chattonella ovata ${ }^{\mathrm{a}}$ & RAP & 33,490 & 3.7 & - & 100 & 1.0 & Jeong et al. (2010) \\
\hline
\end{tabular}

PD, predator volume $\left(\mu \mathrm{m}^{3}\right)$; MIR, maximum ingestion rate $\left(\mathrm{pg} \mathrm{C}\right.$ predator $\left.{ }^{-1} \mathrm{~h}^{-1}\right) ; \mathrm{K}_{\mathrm{IR}}$, mean prey concentration sustaining $1 / 2 \mathrm{MIR}\left(\times 10^{5}\right.$ cells $\left.\mathrm{mL}^{-1}\right)$; $\mathrm{MCR}$, maximum clearance rate $\left(\mathrm{nL}\right.$ predator $\left.{ }^{-1} \mathrm{~h}^{-1}\right)$; VSIR, volume specific ingestion rate $\left(\times 10^{-3} \mathrm{~h}^{-1}\right)$; CIL, ciliate; RAP, raphidophyte; DIN, dinophyte. ${ }^{2}$ The maximum value among the mean ingestion rates measured at given prey concentrations. 
Synechococcus (Guillou et al. 2001). However, the MIR of M. rubrum on Synechococcus was lower than that of Pseudobodo sp. (0.68 cells predator ${ }^{-1} \mathrm{~h}^{-1}$ ) (Dolan and Šimek 1998, Christaki et al. 2002). Therefore, M. rubrum may sometimes compete with the heterotrophic nanoflagellates for the common prey Synechococcus if they co-occur.

\section{Impact of Mesodinium rubum on prey species}

M. rubrum was found to be able to feed on the cyanobacterium Synechococcus sp. as well as the cryptophyte Teleaulax amphioxeia and heterotrophic bacteria (Yih et al. 2004a, Myung et al. 2006). M. rubrum grew well when supplied with T. amphioxeia (Yih et al. 2004a). However,
M. rubrum did not sustain growth when only heterotrophic bacteria or Synechococcus were offered as prey (personal observation, data not shown here). Therefore, Synechococcus may not make a critical contribution to the population growth of M. rubrum in natural environments, but become supplementary prey.

M. rubrum is known to require both food uptake and photosynthesis for sustainable growth. The prey cells are used as sources for energy, carbon, and nutrients. Accordingly, M. rubrum seems to be able to perform photosynthesis using kleptoplastids from a cryptomonad $T$. amphioxeia while taking up heterotrophic bacteria and Synechococcus as phosphorus and nitrogen source.

Table 4. Comparison of ingestion rates and carbon acquisition of protistan grazers on Synechococcus in the literature

\begin{tabular}{|c|c|c|c|c|c|}
\hline Predator species & Taxon & ESD & MIR & MCR & Reference \\
\hline Mesodinium rubrum & CIL & 22.0 & 0.53 & 4.2 & This study \\
\hline Picophagus flagellates & HNF & 2.5 & 0.18 & 2.5 & Guillou et al. (2001) \\
\hline Pseudobodo sp. & HNF & 3.0 & 0.68 & 10.9 & Christaki et al. (2002) \\
\hline Cafeteria roenbergensis & HNF & 3.3 & 0.74 & - & Boenigk et al. (2001) \\
\hline Bodo saltans & HNF & 4.4 & 0.12 & - & Dolan and Šimek (1998) \\
\hline Spumella sp. & HNF & 5.2 & 2.25 & - & Boenigk et al. (2001) \\
\hline Ochromonas sp. & HNF & 6.8 & 9.50 & - & Boenigk et al. (2001) \\
\hline Gonimonas pacifica & CRY & 7.0 & 0.13 & 4.6 & Apple et al. (2011) \\
\hline Heterosigma akashiwo $^{\mathrm{a}}$ & RAP & 11.0 & 0.78 & 300 & Jeong et al. (2010) \\
\hline Symbiodinium voratum & MTD & 11.1 & 1.06 & 165.4 & Jeong et al. (2012) \\
\hline Uronema sp. & CIL & 11.7 & 2.38 & 148.2 & Christaki et al. (1999) \\
\hline Prorocentrum minimum & MTD & 12.1 & 1.20 & - & Jeong et al. (2005) \\
\hline Prorocentrum donghaiense & MTD & 13.2 & 1.54 & 2,600 & Jeong et al. (2005) \\
\hline Oxyrrhis marina & HTD & 14.5 & 1.38 & 42.2 & Apple et al. (2011) \\
\hline Heterocapsa triquetra & MTD & 15.0 & 0.88 & - & Jeong et al. (2005) \\
\hline Alexandrium minutum & MTD & 16.7 & 0.64 & - & Jeong et al. (2005) \\
\hline Gymnodinium impudicum & MTD & 17.8 & 2.90 & - & Jeong et al. (2005) \\
\hline Karenia brevis & MTD & 20.3 & 1.00 & - & Jeong et al. (2005) \\
\hline Scrippsiella trochoidea & MTD & 22.8 & 1.42 & - & Jeong et al. (2005) \\
\hline Cochlodinium polykrikoides & MTD & 25.9 & 7.78 & - & Jeong et al. (2005) \\
\hline Prorocentrum micans & MTD & 26.6 & 7.64 & 4,300 & Jeong et al. (2005) \\
\hline Alexandrium tamarense & MTD & 28.1 & 2.74 & - & Jeong et al. (2005) \\
\hline Akashiwo sanguinea & MTD & 30.8 & 12.6 & - & Jeong et al. (2005) \\
\hline Strombidium sulcatum & CIL & 31.0 & 7.32 & 515.0 & Christaki et al. (1999) \\
\hline Gonyaulax polygramma & MTD & 32.5 & 8.48 & - & Jeong et al. (2005) \\
\hline Alexandrium catenella & MTD & 32.6 & 29.50 & - & Jeong et al. (2005) \\
\hline Gymnodinium catenatum & MTD & 33.9 & 6.04 & - & Jeong et al. (2005) \\
\hline Gonyaulax spinifera & MTD & 35.0 & 4.86 & - & Jeong et al. (2005) \\
\hline Lingulodinium polyedrum & MTD & 38.2 & 12.84 & - & Jeong et al. (2005) \\
\hline Chattonella ovata $^{\mathrm{a}}$ & RAP & 40.0 & 3.72 & 100.0 & Jeong et al. (2010) \\
\hline Eutintinnuis sp. & CIL & 68.0 & 31.00 & 219.0 & Apple et al. (2011) \\
\hline
\end{tabular}

ESD, equivalent spherical diameter $(\mu \mathrm{m}) ; \mathrm{MIR}$, maximum ingestion rate $\left(\mathrm{pg} C\right.$ predator $\left.{ }^{-1} \mathrm{~h}^{-1}\right) ; \mathrm{MCR}$, maximum clearance rate $\left(\mathrm{nL}\right.$ predator $\left.{ }^{-1} \mathrm{~h}^{-1}\right)$; $\mathrm{CIL}$, ciliate; HNF, heterotrophic nanoflagellate; CRY, cryptophyte; RAP, raphidophyte; MTD, mixotrophic dinoflagellate; HTD, heterotrophic dinoflagellate.

The maximum value among the mean ingestion rates measured at given prey concentrations. 


\section{Grazing impact on Synechococcus populations}

The grazing coefficients attributable to M. rubrum on co-occurring Synechococcus spp. in Masan Bay, Korea were affected mostly by the abundance of $M$. rubrum predator. The abundance of M. rubrum and Synechococcus spp. $(\mathrm{n}=40)$ were $11-933$ cells $\mathrm{mL}^{-1}$ and 51-39,509 cells $\mathrm{mL}^{-1}$, respectively. Grazing coefficients attributable to $M$. rubrum on co-occurring Synechococcus spp. were 0.001 to 0.036 day $^{1}$ (Fig. 4).

To our knowledge, prior to this study, there had been no reports on the estimation of grazing impact by Mesodinium on co-occurring populations of Synechococcus. Grazing coefficients derived from studies in Masan Bay in 2004-2005 show that up to 3.6\% of Synechococcus populations can be removed by Mesodinium in approximately 1 day. High mean abundance of Synechococcus (3,568 cell $\mathrm{mL}^{-1}$ ) and relatively low mean abundance of Mesodinium (99 cell $\mathrm{mL}^{-1}$ ) in coastal waters are responsible for the resulted relatively lower grazing coefficients. The results of the present study suggested that M. rubrum was not able to control the whole Synechococcus populations. However, the ingestion rates of protists are known to be affect by light and nutrition conditions (Jeong et al. 1999, Myung et al. 2006, Berge et al. 2008). Therefore, the lower grazing impact of Mesodinium on co-occurring Synechococcus may also be affected by light and nutrients conditions as well as the prey availability.

\section{Ecological significance of Synechococcus feeding by Mesodinium rubrum}

Complex mixotrophy in the marine ciliate Mesodinium rubrum. Unique status of kleptoplastidy in $M$. rubrum was shown by the highly organized chloroplastmitochondria complexes from its cryptophyte prey (Johnson et al. 2007, Nam et al. 2012), long-time functioning of the kleptoplastids (Myung et al. 2013), and even the karyoklepty from the ingested cryptophyte prey cells (Johnson et al. 2007). Bacterivory in M. rubrum was noteworthy as an alternate source of essential microelements and cell carbon (Myung et al. 2006). Present study confirms that $M$. rubrum also feed on Synechococcus cells, one of the most abundant single cell phototrophs in the sea. In the euphotic zone of the oligotrophic open ocean Synechococcus spp. predominates the upper euphotic layers, and sometimes perform nitrogen fixation, to be fed into open ocean food web (Phlips et al. 1989, Walker and Marchant 1989). Equipped with quite unique and complex mixotrophic arrays of metabolism such as

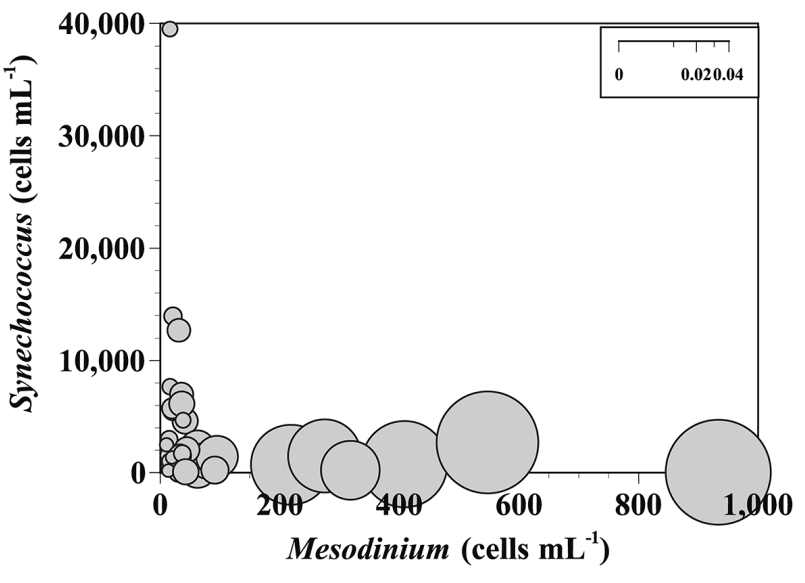

Fig. 4. Calculated grazing coeffienents of Mesodinium rubrum ( $\mathrm{n}=$ 40 ) in relation to the concentration of co-occurring Synechococcus (see text for calculation). Clearance rates measured under the conditions provided in the present study, were corrected using $\mathrm{Q}_{10}=$ 2.8 (Hansen et al. 1997) because in situ water temperatures and the temperature used in the laboratory for this experiment $\left(20^{\circ} \mathrm{C}\right)$ were sometimes different. The scales of the circles in the inset boxes are g day ${ }^{-1}$.

phagotrphy on hetrotrophic bacteria and Synechococcus as well as digestion, kleptoplastidy, and karyoklepty after the ingestion of cryptophyte prey, M. rubrum might be able to form recurrent and massive blooms in diverse marine environments (Crawford 1989, Herfort et al. 2011, Yih et al. 2013).

Metabolic importance of Synechococcus for $\mathrm{Me}$ sodinium rubrum. C requirements for the growth of $M$. rubrum can be met by photosynthesis using kleptoplastids from prey cryptophytes as well as $\mathrm{C}$ from ingested cryptophytes, heterotrophic bacteria, and autotrophic bacteria like Synechococcus spp. (Yih et al. 2004a, Myung et al. 2006, 2011, 2013, Park et al. 2007). Maximum contribution to the growth of $M$. rubrum by ingested cryptophytes, heterotrophic and phototrophic bacteria were estimated to reach $5.5,6.2$, and $1.2 \%$ body carbon ciliate $^{-1}$ day $^{-1}$, respectively (Yih et al. 2004a, Myung et al. 2006).

New trophic pathways from marine phototrophic prokaryotes. Present study showed that M. rubrum is able to feed on phototrophic prokaryotes-the most abundant microorganisms in the ocean (Johnson and Sieburth 1979, Waterbury et al. 1979, Ferris and Palenik 1998). $M$. rubrum has thus long been involved in the newly recognized trophic pathways between diverse marine organisms and Synechococcus, which further emphasizes the ecological importance of M. rubrum as a new model organism with multiple layers of mixotrophy. Currently, more information about the population dynamics of $M$. rubrum is needed to understand the relative importance 
of its Synechococcus feeding for the frequent success of the mixotrophic ciliate in the sea.

\section{CONCLUSION}

Phagotrophy of the phototrophic ciliate Mesodinium rubrum on the cyanobacterium Synechococcus, one of the most abundant single cell phototrophs in the sea, was firstly confirmed by the feeding experiment in the present study. By the unique and complex mixotrophic arrays including phagotrophy on heterotrophic bacteria and Synechococcus as well as digestion, kleptoplastidy and karyoklepty after the ingestion of cryptophyte prey, thus, $M$. rubrum can form recurrent and massive blooms in diverse marine environments. The new trophic pathway from Synechococcus to diverse predators linked by M. rubrum might further emphasize the ecological importance of M. rubrum as a marine model organism with multiple layers of mixotrophy.

\section{ACKNOWLEDGEMENTS}

This paper was supported by the National Research Foundation of Korea (NRF) grants funded by the Korea government (MSIP), (NRF-2015M1A5A1041808, award to W. Yih) and (NRF-2014R1A6A3A01059254, award to Y. D. Yoo), and a KIMST (Korea Institute of Marine Science and Technology Promotion Program, Technical Development for Aquacultural Industrialization award to H. S. Kim and the National Marine Biodiversity Institute Research Program (2015M00100) award to K. A. Seong.

\section{REFERENCES}

Apple, J. K., Strom, S. L., Palenik, B. \& Brahamsha, B. 2011. Variability in protist grazing and growth on different marine Synechococcus isolates. Appl. Environ. Microbiol. 77:3074-3084.

Berge, T., Hansen, P. J. \& Moestrup, Ø. 2008. Feeding mechanism, prey specificity and growth in light and dark of the plastidic dinoflagellate Karlodinium armiger. Aquat. Microb. Ecol. 50:279-288.

Boenigk, J., Matz, C., Jürgens, K. \& Arndt, H. 2001. The influence of preculture conditions and food quality on the ingestion and digestion process of three species of heterotrophic nanoflagellates. Microb. Ecol. 42:168-176. Burkill, P. H., Leakey, R. J. G., Owens, N. J. P. \& Mantoura, R. F.
C. 1993. Synechococcus and its importance to the microbial foodweb of the northwestern Indian Ocean. Deep Sea Res. II Top. Stud. Oceanogr. 40:773-782.

Christaki, U., Courties, C., Karayanni, H., Giannakourou, A., Maravelias, C., Kormas, K. A. \& Lebaron, P. 2002. Dynamic characteristics of Prochlorococcus and Synechococcus consumption by bacterivorous nanoflagellates. Microb. Ecol. 43:341-352.

Christaki, U., Jacquet, S., Dolan, J. R., Vaulot, D. \& Rassoulzadegan, F. 1999. Growth and grazing on Prochlorococcus and Synechococcus by two marine ciliates. Limnol. Oceanogr. 144:52-61.

Crawford, D. W. 1989. Mesodinium rubrum: the phytoplankter that wasn't. Mar. Ecol. Prog. Ser. 58:161-174.

Dolan, J. R. \& Šimek, K. 1998. Ingestion and digestion of an autotrophic picoplankter, Synechococcus, by a heterotrophic nanoflagellate, Bodo saltans. Limnol. Oceanogr. 43:1740-1746.

Fenchel, T. \& Hansen, P. J. 2006. Motile behaviour of the bloom-forming ciliate Mesodinium rubrum. Mar. Biol. Res. 2:33-40.

Ferris, M. J. \& Palenik, B. 1998. Niche adaptation in ocean cyanobacteria. Nature 396:226-228.

Frost, B. W. 1972. Effects of size and concentration of food particles on the feeding behavior of the marine planktonic copepod Calanus pacificus. Limnol. Oceanogr. 17:805-815.

Glibert, P. M., Heil, C. A., Hollander, D. J., Revilla, M., Hoare, A., Alexander, J. \& Murasko, S. 2004. Evidence for dissolved organic nitrogen and phosphorus uptake during a cyanobacterial bloom in Florida Bay. Mar. Ecol. Prog. Ser. 280:73-83.

Glover, H. E., Campbell, L. \& Prézelin, B. B. 1986. Contribution of Synechococcus spp. to size-fractioned primary productivity in three water masses in the Northwest Atlantic Ocean. Mar. Biol. 91:193-203.

Guillard, R. R. L. \& Ryther, J. H. 1962. Studies of marine planktonic diatoms. I. Cyclotella nana Hustedt and Detonula confervacea (Cleve) Grun. Can. J. Microbiol. 8:229-239.

Guillou, L., Jacquet, S., Chrétiennot-Dinet, M. -J. \& Vaulot, D. 2001. Grazing impact of two small heterotrophic flagellates on Prochlorococcus and Synechococcus. Aquat. Microb. Ecol. 26:201-207.

Hansen, P. J., Bjørnsen, P. K. \& Hansen, B. W. 1997. Zooplankton grazing and growth: scaling within the $2-2,000-\mu \mathrm{m}$ body size range. Limnol. Oceanogr. 42:687-704.

Hansen, P. J., Moldrup, M., Tarangkoon, W., Garcia-Cuetos, L. \& Moestrup, Ø. 2012. Direct evidence for symbiont sequestration in the marine red tide ciliate Mesodinium rubrum. Aquat. Microb. Ecol. 66:63-75. 
Hansen, P. J., Nielsen, L. T., Johnson, M., Berge, T. \& Fylnn, K. J. 2013. Acquired phototrophy in Mesodinium and Dinophysis: a review of cellular organization, prey selectivity, nutrient uptake and bioenergetics. Harmful Algae 28:126-139.

Heinbokel, J. F. 1978. Studies on the functional role of tintinnids in the Southern California Bight. I. Grazing and growth rates in laboratory cultures. Mar. Biol. 47:177189.

Herfort, L., Peterson, T. D., McCue, L. A., Crump, B. C., Prahl, F. G., Baptista, A. M., Campbell, V., Warnick, R., Selby, M., Roegner, G. C. \& Zuber, P. 2011. Myrionecta rubra population genetic diversity and its cryptophyte chloroplast specificity in recurrent red tides in the Columbia River estuary. Aquat. Microb. Ecol. 62:85-97.

Huang, S., Wilhelm, S. W., Harvey, H. R., Taylor, K., Jiao, N. \& Chen, F. 2012. Novel lineages of Prochlorococcus and Synechococcus in the global oceans. ISME J. 6:285-297.

Jeong, H. J., Park, J. Y., Nho, J. H., Park, M. O., Ha, J. H., Seong, K. A., Jeng, C., Seong, C. N., Lee, K. Y. \& Yih, W. H. 2005. Feeding by the red-tide dinoflagellates on the cyanobacterium Synechococcus. Aquat. Microb. Ecol. 41:131-143.

Jeong, H. J., Seong, K. A., Kang, N. S., Yoo, Y. D., Nam, S. W., Park, J. Y., Shin, W., Glibert, P. M. \& Johns, D. 2010. Feeding by raphidophytes on the cyanobacterium Synechococcus sp. Aquat. Microb. Ecol. 58:181-195.

Jeong, H. J., Shim, J. H., Kim, J. S., Park, J. Y., Lee, C. W. \& Lee, Y. 1999. Feeding by the mixotrophic thecate dinoflagellate Fragilidium cf. mexicanum on red-tide and toxic dinoflagellates. Mar. Ecol. Prog. Ser. 176:263-277.

Jeong, H. J., Yoo, Y. D., Kang, N. S., Lim, A. S., Seong, K. A., Lee, S. Y., Lee, M. J., Lee, K. H., Kim, H. S., Shin, W., Nam, S. W., Yih, W. \& Lee, K. 2012. Heterotrophic feeding as a newly identified survival strategy of the dinoflagellate Symbiodinium. Proc. Natl. Acad. Sci. U. S. A. 109:12604-12609.

Jeong, H. J., Yoo, Y. D., Lee, K. H., Kim, T. H., Seong, K. A., Kang, N. S., Lee, S. Y., Kim, J. S., Kim, S. \&Yih, W. 2013. Red tides in Masan Bay, Korea in 2004-2005. I. Daily variations in the abundance of red-tide organisms and environmental factors. Harmful Algae 30(Suppl. 1):S75-S88.

Johnson, M. D., Oldach, D., Delwiche, C. F. \& Stoecker, D. K. 2007. Retention of transcriptionally active cryptophyte nuclei by the ciliate Myrionecta rubra. Nature 445:426428.

Johnson, M. D. \& Stoecker, D. K. 2005. Role of feeding in growth and photophysiology of Myrionecta rubra. Aquat. Microb. Ecol. 39:303-312.

Johnson, P. W. \& Sieburth, J. M. 1979. Chroococcoid cyanobacteria in the sea: a ubiquitous and diverse phototrophic biomass. Limnol. Oceanogr. 24:928-935.
Landry, M. R., Kirshtein, J. \& Constantinou, J. 1996. Abundances and distributions of picoplankton populations in the Central Equatorial Pacific from $12^{\circ} \mathrm{N}$ to $12^{\circ} \mathrm{S}, 140^{\circ} \mathrm{W}$. Deep Sea Res. Part II Top. Stud. Oceanogr. 43:871-890.

Lee, K. H., Jeong, H. J., Yoon, E. Y., Jang, S. H., Kim, H. S. \& Yih, W. 2014. Feeding by common heterotrophic dinoflagellates and a ciliate on the red-tide ciliate Mesodinium rubrum. Algae 29:153-163.

Li, W. K. W. 1994. Primary production of prochlorophytes, cyanobacteria, and eukaryotic ultraphytoplankton: measurements from flow cytometric sorting. Limnol. Oceanogr. 39:169-175.

Lignell, R., Seppälä, J., Kuuppo, P., Tammimen, T., Andersen, T. \& Gismervik, I. 2003. Beyond bulk properties: responses of coastal summer plankton communities to nutrient enrichment in the northern Baltic Sea. Limnol. Oceanogr. 48:189-209.

Lindholm, T. 1985. Mesodinium rubrum: a unique photosynthetic ciliate. Adv. Aquat. Microbiol. 3:1-48.

Liu, H., Dagg, M. J. \& Strom, S. 2005. Grazing by the calanoid copepod Neocalanus cristatus on the microbial food web in the coastal Gulf of Alaska. J. Plankton Res. 27:647-662.

Liu, M., Xiao, T., Sun, J., Wei, H., Wu, Y., Zhao, Y. \& Zhang, W. 2013. Bacterial community structures associated with a natural spring phytoplankton bloom in the Yellow Sea, China. Deep Sea Res. Part II Top. Stud. Oceanogr. 97:8592.

Marañón, E., Behrenfeld, M. J., González, N., Mouriño, B. \& Zubkov, M. V. 2003. High variability of primary production in oligotrophic waters of the Atlantic Ocean: uncoupling from phytoplankton biomass and size structure. Mar. Ecol. Prog. Ser. 257:1-11.

Menden-Deuer, S. \& Lessard, E. J. 2000. Carbon to volume relationships for dinoflagellates, diatoms, and other protist plankton. Limnol. Oceanogr. 45:569-579.

Murrell, M. C. \& Lores, E. M. 2004. Phytoplankton and zooplankton seasonal dynamics in a subtropical estuary: importance of cyanobacteria. J. Plankton Res. 26:371382.

Myung, G., Kim, H. S., Park, J. S., Park, M. G. \& Yih, W. 2011. Population growth and plastid type of Myrionecta rubra depend on the kinds of available cryptomonad prey. Harmful Algae 10:536-541.

Myung, G., Kim, H. S., Park, J. W., Park, J. S. \& Yih, W. 2013. Sequestered plastids in Mesodinium rubrum are functionally active up to 80 days of phototrophic growth without cryptomonad prey. Harmful Algae 27:82-87.

Myung, G., Yih, W., Kim, H. S., Park, J. S. \& Cho, B. C. 2006. Ingestion of bacterial cells by the marine photosynthetic ciliate Myrionecta rubra. Aquat. Microb. Ecol. 44:175- 
180.

Nam, S. W., Shin, W., Coats, D. W., Park, J. W. \& Yih, W. 2012. Ultrastructure of the oral apparatus of Mesodinium rubrum from Korea. J. Eukaryot. Microbiol. 59:625-636.

Ong, L. J. \& Glazer, A. N. 1991. Phycoerythrins of marine unicellular cyanobacteria. I. Bilin types and locations and energy transfer pathways in Synechococcus spp. phycoerythrins. J. Biol. Chem. 266:9515-9527.

Park, J. S., Myung, G., Kim, H. S., Cho, B. C., Yih, W. 2007. Growth responses of the marine photosynthetic ciliate Myrionecta rubra to different cryptomonad strains. Aquat. Microb. Ecol. 48:83-90.

Park, M. G., Kim, S., Kim, H. S., Myung, G., Kang, Y. G. \& Yih, W. 2006. First successful culture of the marine dinoflagellate Dinophysis acuminata. Aquat. Microb. Ecol. 45:101-106

Phlips, E. J., Zeman, C. \& Hansen, P. 1989. Growth, photosynthesis, nitrogen fixation and carbohydrate production by a unicellular cyanobacterium, Synechococcus sp. (Cyanophyta). J. Appl. Phycol. 1:137-145.

Powell, L. M., Bowman, J. P., Skerratt, J. H., Franzmann, P. D. \& Burton, H. R. 2005. Ecology of a novel Synechococcus clade occurring in dense populations in saline Antarctic lakes. Mar. Ecol. Prog. Ser. 291:65-80.

Reguera, B., Velo-Suárez, L., Raine, R. \& Park, M. G. 2012. Harmful Dinophysis species: a review. Harmful Algae 14:87-106

Sherr, B. F., Sherr, E. B. \& Fallon, R. D. 1987. Use of monodispersed, fluorescently labeled bacteria to estimate in situ protozoan bacterivory. Appl. Environ. Microbiol.
53:958-965.

Strom, S. L., Brahamsha, B., Fredrickson, K. A., Apple, J. K. \& Rodríguez, A. G. 2012. A giant cell surface protein in Synechococcus WH8102 inhibits feeding by a dinoflagellate predator. Environ. Microbiol. 14:807-816.

Sullivan, L. J. \& Gifford, D. J. 2004. Diet of the larval ctenophore Mnemiopsis leidyi A. Agassiz (Ctenophora, Lobata). J. Plankton Res. 26:417-431.

Taylor, F. J. R., Blackbourn, D. J. \& Blackbourn, J. 1971. The red-water ciliate Mesodinium rubrum and its "incomplete symbionts": a review including new ultrastructural observations. J. Fish. Res. Board Can. 28:391-407.

Walker, T. D. \& Marchant, H. J. 1989. The seasonal occurrence of chroococcoid cyanobacteria at an Antarctic coastal site. Polar Biol. 9:193-196.

Waterbury, J. B., Watson, S. W., Guillard, R. R. L. \& Brand, L. E. 1979. Widespread occurrence of a unicellular, marine, planktonic cyanobacterium. Nature 277:293-294.

Yih, W., Kim, H. S., Jeong, H. J., Myung, G. \& Kim, Y. G. $2004 a$. Ingestion of cryptophyte cells by the marine photosynthetic ciliate Mesodinium rubrum. Aquat. Microb. Ecol. 36:165-170.

Yih, W., Kim, H. S., Myung, G. \& Kim, Y. G. 2004b. Rapid feeding on live organisms of the phototrophic ciliate $\mathrm{Me}$ sodinium rubrum by Farrer's Scallop Chlamys farreri. J. Mar. Biotechnol. 6:142-145.

Yih, W., Kim, H. S., Myung, G., Park, J.W., Yoo, Y. D. \& Jeong, H. J. 2013. The red-tide ciliate Mesodinium rubrum in Korean coastal waters. Harmful Algae 30(Suppl. 1):S53-S61. 